medRxiv preprint doi: https://doi.org/10.1101/2020.04.27.20080309; this version posted May 1, 2020. The copyright holder for this preprint (which was not certified by peer review) is the author/funder, who has granted medRxiv a license to display the preprint in perpetuity.

All rights reserved. No reuse allowed without permission.

\title{
Serial measurements in COVID-19-induced acute respiratory disease to unravel heterogeneity of the disease course: design of the Maastricht Intensive Care COVID cohort; MaastrICCht
}

Maastricht Intensive Care COVID Study Group; MaastrICCht Collaborators

Jeanette Tas ${ }^{1,2}{ }^{*}$, Rob J.J. van Gassel ${ }^{1,3,4}$ *, Serge J.H. Heines ${ }^{1}$, Mark M.G. Mulder ${ }^{1}$, Nanon F.L. Heijnen ${ }^{1}$, Melanie J. Acampo-de Jong ${ }^{1}$, Julia L.M. Bels ${ }^{1}$, Frank C. Bennis ${ }^{1}$, Marcel Koelmann', Rald V.M. Groven ${ }^{1}$, Moniek A. Donkers ${ }^{1}$, Frank van Rosmalen ${ }^{1,5,6}$, Ben J.M. Hermans $^{1,6}$, Steven J.R. Meex ${ }^{7}$, Alma M.A. Mingels ${ }^{7}$, Otto Bekers ${ }^{7}$, Paul H.M. Savelkoul ${ }^{8}$, Astrid M.L Oude Lashof ${ }^{8}$, Joachim E. Wildberger ${ }^{9}$, Maastricht Intensive Care COVID Study Group, Fabian H. Tijssen ${ }^{10}$, Wolfgang F.F.A. Buhre ${ }^{10}$, Jan-Willem E.M. Sels ${ }^{1,11}$, Chahinda Ghossein-Doha ${ }^{1,11}$, Rob G.H. Driessen ${ }^{1,11}$, Pieter L. Kubben ${ }^{12}$, Marcus L.F. Janssen ${ }^{13}$, Gerry A.F. Nicolaes ${ }^{14}$, Uli Strauch ${ }^{1}$, Zafer Geyik ${ }^{1,11}$, Thijs S.R. Delnoy ${ }^{1,11}$, Kim H.M. Walraven ${ }^{15}$, Coen D.A. Stehouwer ${ }^{6,16}$, Jeanine A.M.C.F. Verbunt ${ }^{17}$, Walther N.K.A van Mook ${ }^{1}$, Susanne van Santen ${ }^{1}$, Ronny M. Schnabel ${ }^{1}$, Marcel J.H. Aries ${ }^{1,2}$, Marcel C.G. van de Poll ${ }^{1,3,4}$, Dennis C.J.J Bergmans $^{1}$, Iwan C.C. van der Horst ${ }^{1,6}$, Sander M.J. van Kuijk ${ }^{18}$, Bas C.T. van Busse ${ }^{1}$

${ }^{*}$ Both collaborators/authors contributed equally. 
medRxiv preprint doi: https://doi.org/10.1101/2020.04.27.20080309; this version posted May 1, 2020. The copyright holder for this preprint (which was not certified by peer review) is the author/funder, who has granted medRxiv a license to display the preprint in perpetuity.

All rights reserved. No reuse allowed without permission.

Affiliations:

1. Department of Intensive Care, Maastricht University Medical Center+, Maastricht, the Netherlands

2. School for Mental Health and Neuroscience (MHeNS), Maastricht University Medical Center+, Maastricht, The Netherlands

3. Department of Surgery, Maastricht University Medical Center+, Maastricht, the Netherlands

4. School of Nutrition and Translational Research in Metabolism (NUTRIM), Maastricht University, Maastricht, the Netherlands

5. Department of Biomedical Engineering, Maastricht University, Maastricht, the Netherlands

6. Cardiovascular Research Institute Maastricht (CARIM), Maastricht, the Netherlands

7. Department of Clinical Chemistry, Maastricht University Medical Center+, Maastricht, the Netherlands

8. Department of Medical Microbiology, Maastricht University Medical Center+, Maastricht, the Netherlands

9. Department of Radiology and Nuclear Medicine, Maastricht University Medical Center+, Maastricht, the Netherlands

10. Department of Anaesthesiology and Pain Medicine, Maastricht University Medical Center+, Maastricht, the Netherlands

11. Department of Cardiology, Maastricht University Medical Center+, Maastricht, the Netherlands

12. Department of Neurosurgery, Maastricht University Medical Center+, Maastricht, the Netherlands

13. Department of Neurology and Clinical Neurophysiology, Maastricht University Medical Center+ Maastricht, the Netherlands

14. Department of Biochemistry, Cardiovascular Research Institute Maastricht (CARIM), Maastricht, the Netherlands 
medRxiv preprint doi: https://doi.org/10.1101/2020.04.27.20080309; this version posted May 1, 2020. The copyright holder for this preprint (which was not certified by peer review) is the author/funder, who has granted medRxiv a license to display the preprint in perpetuity.

All rights reserved. No reuse allowed without permission.

15. Department of Pulmonology, Maastricht University Medical Center+, Maastricht, the Netherlands

16. Department of Internal Medicine, Maastricht University Medical Center+, Maastricht, the Netherlands

17. Department of Rehabilitation Medicine, Adelante and Maastricht University Medical Center+, Maastricht, the Netherlands

18. Department of Clinical Epidemiology and Medical Technology Assessment, Maastricht University Medical Center+, Maastricht, the Netherlands

Short title: to unravel clinical heterogeneity in COVID-19-induced acute respiratory disease

Keywords: cohort study, design, repeated data, COVID-19, SARS-CoV-2, aetiology, diagnostics, prognostics, longitudinal

\section{Corresponding author:}

Bas C.T. van Bussel, MD PhD

Department of Intensive Care, Maastricht University Medical Center+

P. Debyelaan 25

6229 HX Maastricht

The Netherlands

E-mail: $\underline{\text { bas.van.bussel@mumc.nl }}$

Telephone: $+31(0) 43-3861302$ 
medRxiv preprint doi: https://doi.org/10.1101/2020.04.27.20080309; this version posted May 1, 2020. The copyright holder for this preprint (which was not certified by peer review) is the author/funder, who has granted medRxiv a license to display the preprint in perpetuity.

All rights reserved. No reuse allowed without permission.

\section{ABSTRACT}

Background: The course of the disease in severe acute respiratory syndrome coronavirus 2 (SARS-CoV-2) infection in mechanically ventilated patients is unknown. To unravel the clinical heterogeneity of the SARS-CoV-2 infection in these patients, we designed the prospective observational Maastricht Intensive Care COVID cohort; MaastrICCht. We incorporated serial measurements that harbour aetiological, diagnostic and predictive information. The study aims to investigate the heterogeneity of the natural course of critically ill patients with SARS-CoV-2 infection.

Study population: Mechanically ventilated patients admitted to the Intensive Care with SARSCoV-2 infection.

Main message: We will collect clinical variables, vital parameters, laboratory variables, mechanical ventilator settings, chest electrical impedance tomography, electrocardiograms, echocardiography as well as other imaging modalities to assess heterogeneity of the natural course of SARS-CoV-2 infection in critically ill patients. The MaastrlCCht cohort is, also designed to foster various other studies and registries and intends to create an open-source database for investigators. Therefore, a major part of the data collection is aligned with an existing national Intensive Care data registry and two international COVID-19 data collection initiatives. Additionally, we create a flexible design, so that additional measures can be added during the ongoing study based on new knowledge obtained from the rapidly growing body of evidence.

Conclusion: The spread of the COVID-19 pandemic requires the swift implementation of observational research to unravel heterogeneity of the natural course of the disease of SARSCoV-2 infection in mechanically ventilated patients. Our design is expected to enhance aetiological, diagnostic and prognostic understanding of the disease. This paper describes the design of the MaastrICCht cohort. 
medRxiv preprint doi: https://doi.org/10.1101/2020.04.27.20080309; this version posted May 1 , 2020. The copyright holder for this preprint (which was not certified by peer review) is the author/funder, who has granted medRxiv a license to display the preprint in perpetuity.

All rights reserved. No reuse allowed without permission.

\section{Strengths and limitations of this study}

- Serial measurements that characterize the disease course of SARS-CoV-2 infection in mechanically ventilated patients

- Data collection and analysis according to a predefined protocol

- Flexible, evolving design enabling the study of multiple aspects of SARS-CoV-2 infection in mechanically ventilated patients

- Single centre, including only ICU patients 
medRxiv preprint doi: https://doi.org/10.1101/2020.04.27.20080309; this version posted May 1 , 2020. The copyright holder for this preprint (which was not certified by peer review) is the author/funder, who has granted medRxiv a license to display the preprint in perpetuity.

\section{INTRODUCTION}

Severe acute respiratory syndrome coronavirus 2 (SARS-CoV-2) infection is highly heterogeneous in its presentation.[1-3] Approximately $40 \%$ of patients show no clinical signs, $40 \%$ have a mild illness, whereas around $20 \%$ require hospitalisation, of whom $5-10 \%$ develop a critical disease that requires mechanical ventilation.[4] The SARS-CoV-2 disease course in mechanically ventilated patients is unknown, while the COVID-19 pandemic, caused by SARSCoV-2, stresses Intensive Care resources to maximum capacity in pandemic areas such as the Netherlands.[5] Compared to other regions in the world[6], we had time to plan, with the advantage to design a study that investigates heterogeneity of the disease course over time.

We hypothesize that a comprehensive characterization of the heterogeneity of the natural course of critically ill patients with SARS-CoV-2 will enhance our aetiologic, diagnostic and prognostic understanding of the disease, which ultimately helps to guide Intensive Care resources and patient care. Therefore, we initiated the Maastricht Intensive Care COVID cohort; MaastrICCht. We intend to collect a broad set of clinical variables and biomarkers serially over time that precede the outcome in mechanically ventilated patients infected with SARS-CoV-2. Unfamiliarity with SARS-CoV-2 infection and its disease course raises many aetiologic, diagnostic and prognostic questions in Intensive Care practice. For example, how does lung compliance develop over the course of the infection? How does multi-organ failure develop over the course of the disease for patients that survive vs those that do not? What are the cardiovascular complications that can be diagnosed early? Which patients develop thrombosis?[7] Is thrombotic risk driven by inflammation and affected by comorbidities, such as obesity, type 2 diabetes mellitus and the presence of cardiovascular disease?[3, 7] Does immobilisation by a neuromuscular blockade, also, play a role?[8] Serial data to investigate such topics are scare.[9, 10]

The COVID-19 pandemic required swift implementation observational research activities to unravel the clinical changes in the course of the disease that precede favourable or worse outcome in mechanically ventilated patients with a SARS-CoV-2 infection admitted to the Intensive Care. We intend to use serial measurements to investigate the aetiology, 
medRxiv preprint doi: https://doi.org/10.1101/2020.04.27.20080309; this version posted May 1, 2020. The copyright holder for this preprint (which was not certified by peer review) is the author/funder, who has granted medRxiv a license to display the preprint in perpetuity.

All rights reserved. No reuse allowed without permission.

diagnostic and prognostic value of respiratory variables (i.e. ventilator settings, prone positioning, chest electric impedance tomography (EIT))[11-14], cardiovascular variables (laboratory variables, electrocardiograms, echocardiograms and chest computed tomography (CT) scans)[10], metabolic variables (kidney function, liver biochemistry and electrolytes) and thrombotic complications (laboratory variables, thrombotic events) amongst others as described below. We describe the design of the MaastrlCCht cohort in detail.

\section{METHOD AND ANALYSIS}

\section{Participants}

This prospective cohort study is conducted in patients admitted to the Intensive Care of the Maastricht University Medical Center (Maastricht UMC+), a tertiary teaching hospital in the southern part of the Netherlands. Usually, our Intensive Care Unit (ICU) has 27 beds, divided over three subunits to which all types of critically ill patients are admitted. However, to provide care for patients during the COVID-19 pandemic, our ICU underwent a rapid stepwise upgrade to a maximum of 64 beds, consisting of six subunits covering 52 beds for COVID-19 patients and two subunits covering 12 beds for Intensive Care patients without COVID-19. Therefore, our subunits of the ICU are located in the department of Anaesthesiology as well. The local institutional review board (Medisch Ethische Toetsingscomissie (METc) 2020-1565/ 300523) of the Maastricht UMC+ approved the study, which will be performed based on the regulations of Helsinki.

We intend to include all patients admitted to one of our six COVID IC subunits. Patients are intubated and mechanically ventilated and have signs and symptoms of a viral infection and a PCR positive for SARS-CoV-2 and/or a chest CT scan scored positive based on a CORADS-score of $4-5$ by a radiologist.[15] Patients can be admitted via our emergency department, via non-ICU wards and by transportation from other ICUs either for tertiary care referral or due to lack of bed availability in the regional hospitals. 
medRxiv preprint doi: https://doi.org/10.1101/2020.04.27.20080309; this version posted May 1 , 2020. The copyright holder for this preprint (which was not certified by peer review) is the author/funder, who has granted medRxiv a license to display the preprint in perpetuity.

All rights reserved. No reuse allowed without permission.

\section{Registry and research questions}

We developed a protocol for this prospective cohort that contains variables of interest, based on existing literature and based on variables of interest of study initiatives from other centres and study groups (please see below).[16, 17] Many cohort studies in patients with COVID-19 collect similar variables. We sought to collect all of these variables to be able to address a broad range of research questions. We established our list of variables to be retrieved (supplemental Table 1), which we intend to extend in the future. Furthermore, we developed a uniform protocol for patient charts during admission to allow for uniform collection of variables. Thus, we designed the cohort study to register a baseline set of clinical, biochemical and COVID-19 specific variables, and to collect all relevant outcome variables. Additionally, we will record clinical data each day during ICU admission for patients included in the cohort.

A major advantage of this approach is that all variables collected for this cohort are part of routine clinical care but are now collected uniformly and reported in a predefined format. This prospective cohort will serve as an open-source database for other investigators to submit requests for data. The cohort steering committee will consider all requests. To foster data sharing in the future, we chose to align a major part of data collection with an existing Intensive Care data registry and two international COVID-19 data collection initiatives, in a way that is in line with the Findable, Accessible, Interoperable, and Reusable (FAIR) data principle.[18] Our design thereby enables the contribution of data to other initiatives. A data-sharing agreement and plan, approved by the local institutional review board, will be necessary to share data of the MaastrICCht cohort with other data collection initiatives. Also, the cohort is designed in such a way that additional measures can be added during the study period based on new knowledge obtained from the rapidly growing body of evidence. Approval by the local institutional review board will be necessary to add additional measurements that are not part of routine clinical care.

The first primary aim is to investigate the course of COVID-19 respiratory disease during mechanical ventilation. For this, we will use the ventilator setting and chest EIT. Additionally, we intend to investigate the role of prone positioning in the course of the disease. 
medRxiv preprint doi: https://doi.org/10.1101/2020.04.27.20080309; this version posted May 1 , 2020. The copyright holder for this preprint (which was not certified by peer review) is the author/funder, who has granted medRxiv a license to display the preprint in perpetuity.

All rights reserved. No reuse allowed without permission.

The second primary aim will be to describe and investigate cardiovascular changes over time that determine incident thrombosis during mechanical ventilation of COVID-19 patients. Here, we will focus on cardiovascular biomarkers, such as biochemical markers of inflammation and coagulation, and markers of cardiac structure and function (i.e. electrocardiogram, echocardiography and chest CT scans). Third, we will investigate the development of multiorgan failure and compare its disease course for patients that survive vs those that decease. Research questions are organized according to the type of research, e.g. aetiology, diagnostic and prognostic, and examples are shown in Table 1.[5] 
medRxiv preprint doi: https://doi.org/10.1101/2020.04.27.20080309; this version posted May 1, 2020. The copyright holder for this preprint (which was not certified by peer review) is the author/funder, who has granted medRxiv a license to display the preprint in perpetuity.

All rights reserved. No reuse allowed without permission.

Table 1 | Research questions in COVID-19 induced respiratory disease in an Intensive Care population on mechanical ventilation

\begin{tabular}{ll}
$\begin{array}{l}\text { Research } \\
\text { question }\end{array}$ & \multicolumn{1}{c}{ Aetiology } \\
\hline 1 & $\begin{array}{l}\text { Is the development of dynamic compliance and chest EIT parameters more } \\
\text { favorable in survivors as compared to deceased? }\end{array}$ \\
2 & $\begin{array}{l}\text { Is the development of multi-organ failure worse in deceased as compared to } \\
\text { survivors? }\end{array}$ \\
3 & Is an increase in d-dimer, fibrinogen, C-reactive protein and ferritin plasma \\
& concentrations over time greater in patients with incident thrombosis?
\end{tabular}

\section{Diagnosis}

\begin{tabular}{ll}
\hline 4 & Do ECG changes over time discriminate between incident thrombosis? \\
5 & Does SOFA score changes discriminate between death or survival? \\
6 & Does prone, versus supine, positioning determine a favourable improvement in \\
& PF ratio over time? \\
7 & Does EIT, dynamic compliance, ARDS PEEP/FiO ${ }_{2}$ or clinical opinion diagnose \\
& optimal PEEP best?
\end{tabular}

\section{Prognosis}

$8 \quad$ Can conventional risk scores predict outcome in COVID-19 patients?

$9 \quad$ How do newly developed risk scores perform in our cohort?[19-23]

$10 \quad$ Can chest EIT predict prone positioning?

11 Can changes in PF ratio during the first 72 hours predict prone positioning?

12 Are serially measured coagulation tests able to predict adverse thromboembolic and mortality events during the course of the disease?

13 Does acute kidney injury burden predict mortality events during the course of the disease?[24] 
medRxiv preprint doi: https://doi.org/10.1101/2020.04.27.20080309; this version posted May 1, 2020. The copyright holder for this preprint (which was not certified by peer review) is the author/funder, who has granted medRxiv a license to display the preprint in perpetuity.

All rights reserved. No reuse allowed without permission.

\section{Data collection}

The design and serial data collection enable aetiological, diagnostic and prognostic research, and we will first focus on the topics of respiratory and cardiovascular disease and multi-organ failure. The flexible cohort design will allow us investigation of additional topics based on our extensive set of baseline and serial measurements (supplemental Table 1). All variables and measurements are predefined in our study protocol. Inclusion and collection of variables are performed by medical research interns and $\mathrm{PhD}$ candidates not involved in patient care. Data collection for this cohort has started on March $25^{\text {th }}, 2020$ and will be continued without a predefined end-date.

For the baseline characteristics, we will collect data that is aligned with the Dutch National Intensive Care (NICE) data registry and two international COVID-19 data collection initiatives. First, we will collect the minimal dataset of the NICE registry (https://www.stichtingnice.nl/), which includes data from each ICU across the Netherlands. The minimal dataset is the core registration that includes demographic, admission and discharge data of Dutch Intensive Care patients.[25] Second, we will collect data on the COVID-19 case report forms (CRF) of the International Severe Acute Respiratory and Emerging Infection Consortium (ISARIC) and World Health Organisation (WHO).[26] This ISARIC/WHO tool queries symptoms of clinical infection, comorbidities, pathogen testing, therapy and outcome variables. Third, we will collect data fostering the Cardiac complicAtions in Patients with SARS Corona virus 2 regisTrY (CAPACITY), which is an extension of the COVID-19 CRF and of the WHO list that additionally queries cardiac history, diagnostics and occurrence of cardiovascular complications in COVID-19 patients.[27] Fourth, by collecting a vast number of additional variables (both from records and monitors) uniformly, we will be able to merge our cohort to address additional questions in collaboration with others. 
medRxiv preprint doi: https://doi.org/10.1101/2020.04.27.20080309; this version posted May 1, 2020. The copyright holder for this preprint (which was not certified by peer review) is the author/funder, who has granted medRxiv a license to display the preprint in perpetuity.

All rights reserved. No reuse allowed without permission.

\section{Serial chest electrical impedance tomography}

In our department, chest EIT is performed by specialist ventilation practitioners and is available if considered indicated to support clinical practice in patients with respiratory failure and thus is not performed in each patient each day.[14] During the upscaling of COVID-19 ICU subunits, the team of ventilation practitioners was extended with trained medical research interns and technical physicians to cover serial chest EIT measurements in each of the six COVID ICU subunits. Data collection on chest EIT was supervised by the specialist ventilation practitioners.

For the MaastrICCht cohort, our specialist ventilation practitioner team will start the first chest EIT measurement in each admitted patient after intubation as soon as clinically and logistically possible. We intend to obtain measurements in every mechanically ventilated COVID-19 patient with intervals of 2-3 days during their ICU admission, if feasible, and, in particular, after changing clinical conditions, i.e. a change in ventilator settings [28], clinical respiratory deterioration and changes in positioning (i.e. prone-supine and vice versa). If the patient stabilizes and receives pressure support ventilation, chest EIT measurement frequency will decrease, and one to two measurements will be done during the further course of the disease, while on mechanical ventilation. Our chest EIT measurement protocol has been aligned with the chest EIT protocol of the Erasmus University Medical Center, Rotterdam, The Netherlands, to enable pooling of chest EIT data in collaboration [11-14, 29], and is described in the supplement.

\section{Serial clinical, physiological and laboratory measurements}

We intend to collect daily clinical and physiological variables, laboratory variables, electrocardiography, and medication use (please see supplemental Table 1).[30, 31] Consequently, a standard set of plasma and serum biomarkers will be measured daily. Also, for each serum blood sample, the leftover serum will be collected by our Clinical Chemistry department and stored for future biomarker studies. 
medRxiv preprint doi: https://doi.org/10.1101/2020.04.27.20080309; this version posted May 1, 2020. The copyright holder for this preprint (which was not certified by peer review) is the author/funder, who has granted medRxiv a license to display the preprint in perpetuity.

All rights reserved. No reuse allowed without permission.

\section{Additional measurements}

We intend to collect data from echocardiography, chest X-rays and chest CT-scans performed in daily care.[32] The latter will be performed for primary pulmonary assessment (acquired as non-contrast triage scans) [33], or for dedicated cardiovascular assessment (based on contrast-enhanced CT scans).

\section{Outcome variables}

We collect information on events and complications in all patients. We record variables on intubation and extubation, need for extracorporeal membrane oxygenation [34] and need for renal replacement therapy, thrombo-embolic events and resuscitation.[35] We collect data on time to discharge and need for readmission. In case a patient decease, an intensivist will define the cause of death.[36, 37]

\section{Data management}

A customized electronic case report form (e-CRF) was developed and implemented for the current MaastriCCht cohort, using CASTOR (version 2020.18). Independent study monitoring of the organisation and the conduct of the study was in adherence to the Good Clinical Practice guidelines. All variables were considered in daily care and led to decisions on diagnostics and interventions.

\section{Outline of the statistical analyses plan}

All reports will be written following reporting guidelines appropriate for the type of study (i.e., STROBE for observational studies, STARD for diagnostic studies, TRIPOD for prognostic studies; see the Enhancing the QUAlity and Transparency Of health Research network at www.equator-network.org for detailed information). We will describe baseline characteristics of the study sample as means \pm standard deviation (SD), median and interquartile range (IQR), and percentages, as appropriate. P-values will be interpreted according to the American Statistical Association's Statement on Significance and P-Values.[38] All external researchers 
medRxiv preprint doi: https://doi.org/10.1101/2020.04.27.20080309; this version posted May 1, 2020. The copyright holder for this preprint (which was not certified by peer review) is the author/funder, who has granted medRxiv a license to display the preprint in perpetuity.

All rights reserved. No reuse allowed without permission.

submitting a data request will be required to produce a statistical analysis plan that will be reviewed by the cohort steering committee. A summary of the statistical analysis plan for the currently planned research questions is summarized below.

In case of incomplete variables, data will be imputed if the proportion of incomplete patients is over $5 \%$, excluding longitudinal measures that will be analysed using generalized linear mixed-effects regression. Multiple imputation will be used with the percentage of incomplete patients as the number of imputations. Predictive mean matching will be used to draw values to be imputed, as this is more robust to misspecification of the imputation model. If applicable, the results of multiply-imputed data will be pooled using Rubin's Rules. In other cases, results will be pooled using available pooling methods.

Aetiological research questions: In order to use all serial data, we will use flexible longitudinal data analyses techniques, such as generalized linear mixed-effects models. Where applicable, we will model longitudinal and time-to-event data simultaneously using a joint model in case of survival endpoints compared to binary endpoints. First, we will categorize the sample into groups of predefined outcomes, such as survivor vs deceased, responder/nonresponder to prone positioning; and presence vs absence of thrombotic events. Then, we will model the preceding serial data over time for these categories. After reporting the crude results of the generalized linear mixed-effects models, the models will be extended with covariates to adjust for potential confounders. Confounders will be retained in the model according to the method of Rothman[39], if they significantly contribute to the model, as quantified by the Akaike Information Criterion, or if they improve the precision of the estimated treatment effect. Effectmodification will be examined for sex and based on pre-specified hypotheses. Results are reported as effect size with $95 \%$ confidence intervals $(\mathrm{Cl})$.

Diagnostic and prognostic research questions: Diagnostic and prognostic modelling will be performed with a minimum of ten events per variable that is regarded as a candidate diagnostic or prognostic variable. Variable selection will be performed using the Akaike Information Criterion to arrive at a more parsimonious model. Internal validation will be estimated using bootstrap resampling. In each bootstrap sample, the model fitting steps will 
medRxiv preprint doi: https://doi.org/10.1101/2020.04.27.20080309; this version posted May 1 , 2020. The copyright holder for this preprint (which was not certified by peer review) is the author/funder, who has granted medRxiv a license to display the preprint in perpetuity.

All rights reserved. No reuse allowed without permission.

be repeated. The bootstrap resampling yields a shrinkage factor that will be used to shrink the coefficients towards 0 to compensate for overfitting (i.e., the phenomenon that a model performs best on the data used to develop it). Also, the bootstrap internal validation will yield measures of performance adjusted for optimism (i.e., it estimates measures of performance in future patients). Model performance will be quantified using estimates of model fit (i.e. Nagelkerke's R-squared), of discriminative ability (the area under the receiver operating characteristic curve, or AUC, including $95 \% \mathrm{Cl}$ ), and calibration, by visually inspecting a calibration plot. If applicable, the model outcome will be dichotomized and test characteristics, such as sensitivity, specificity, positive and negative likelihood ratio, will be computed.

No previous studies exist that included combinations of serial measurements of clinical variables and biomarkers with outcome in mechanically ventilated COVID-19 patients in the ICU. The lack of previous literature makes it challenging to calculate sample size. In a pragmatic approach, with a world-wide requirement of understanding COVID-19 pathophysiology in mechanically ventilated patients, we chose a stepwise release of cohort data and locked the data collection for the first time at April $19^{\text {th }}, 2020$, to release the first data as timely as possible. The results of this first data collection will be reported shortly.

\section{FUTURE PERSPECTIVES}

Data from this cohort will be released in a stepwise approach, so that in this acute phase most pressing research questions can be addressed, but that the accumulation of data will produce ever-larger datasets for future research projects. If the same hypothesis will be tested over multiple data exports, we plan to correct for sequential testing.[40] We also aim to analyse the electrocardiograms, echocardiography and CT imaging results that are acquired now for later analyses. In addition, the stored serum samples will be used for further biomarker research. We will collect data on extracorporeal membrane oxygenation, which can support the extracorporeal life support organization registry.[41] Also, we intend to analyse microbiology results as, for example, fast replication of RNA viruses is known to introduce mutations in viral replication. Replication mutations may introduce more or less virulent strains that infect 
medRxiv preprint doi: https://doi.org/10.1101/2020.04.27.20080309; this version posted May 1 , 2020. The copyright holder for this preprint (which was not certified by peer review) is the author/funder, who has granted medRxiv a license to display the preprint in perpetuity.

All rights reserved. No reuse allowed without permission.

humans. It remains unclear whether the most virulent SARS-CoV-2 strains of a total heterogeneous SARS-CoV-2 pool, in particular, are relevant for the course of the disease in infected patients who develop a critical illness.

Furthermore, the rapid spread of COVID-19 in the Netherlands required swift transfers of mechanically ventilated patients from smaller hospitals to our tertiary teaching hospital and from our hospital to Germany in several cases.[42, 43] The study design includes potential to address whether transferred patients' disease course and outcome differ from other admitted patients. Moreover, regional differences in outcome, both within our national as in comparison to Belgium and Germany can be explored.

In addition, we plan a long-term follow-up via outpatient clinic visits to evaluate the quality of life of survivors and will collaborate with rehabilitation medicine specialists.[44] Later, when the COVID-19 pandemic recedes, we will modify the ongoing cohort data collection to investigate and observe pathophysiological changes in other clinical variables and novel biomarkers of interest that precede favourable and worse outcome in non-COVID-19 patients at the Intensive Care.

\section{Strengths and limitations}

Our cohort study design has several strengths. First, the study is prospective by design and allows for many serial measurements in SARS-CoV-2 infected patients over time. Second, systematic data collection is performed using a predefined protocol. Next, the data collection is in line with the FAIR data principle and combines a national Intensive Care data registry and two COVID-19 data collection initiatives. Another strength is the flexible design of the cohort and the organisation. This allows extending the variable list soon. Later, the on-going cohort study's focus can easily be redefined to allow investigation of new pathophysiological concepts using new techniques or biomarkers in relation to outcome of Intensive Care patients. Our study is a cross-departmental joint approach throughout Maastricht UMC+ and in the region. A limitation of the study is the single centre approach and thereby a relatively small sample size, although the sample size of certain research questions is enlarged by merging our data 
medRxiv preprint doi: https://doi.org/10.1101/2020.04.27.20080309; this version posted May 1, 2020. The copyright holder for this preprint (which was not certified by peer review) is the author/funder, who has granted medRxiv a license to display the preprint in perpetuity.

All rights reserved. No reuse allowed without permission.

with data from other research groups, as is anticipated. Furthermore, the growing body of evidence during the COVID-19 pandemic might amend therapy over time and this could affect studying the course of the disease. However, on the patient level, we intend to collect data on therapy daily and this will shed light on the course of therapeutic alterations within the cohort over time. Also, the stepwise data release might impair the power of the initial analyses. However, the fast spread of the SARS-CoV-2 virus affects patients world-wide and requires data to guide clinical decisions.[6] Another limitation is that we include only patients admitted to the ICU.[45] Observations made in our study may be generalized to critically ill patients, only. To shed some light on possible selection mechanisms for ICU admission, we intend to compare our cohort with hospitalized non-ICU patients with SARS-CoV-2 infection. However, no further exclusion criteria are determined. Hence, a heterogeneous sample of patients admitted to the ICU is expected. Our inclusion strategy thereby reduces the chance of selection bias, which contributes to the internal validity of the result for mechanically ventilated COVID19 patients.

\section{Collaborations}

We have described the study design and data collection. Our approach aims to combine and compare the cohort data with the Dutch NICE registry, with other COVID-19 data collection initiatives such as the ISARIC and WHO data collections, and with COVID-19 chest EIT data from the Intensive Care of the Erasmus University Medical Center, Rotterdam, the Netherlands among others. 
medRxiv preprint doi: https://doi.org/10.1101/2020.04.27.20080309; this version posted May 1 , 2020. The copyright holder for this preprint (which was not certified by peer review) is the author/funder, who has granted medRxiv a license to display the preprint in perpetuity.

All rights reserved. No reuse allowed without permission.

\section{CONCLUSION}

The COVID-19 pandemic requires the swift implementation of observational research activities to unravel the heterogeneity of the natural course of critically ill patients with SARS-CoV-2. Prospective serial uniform measurements will enhance our aetiologic, diagnostic and prognostic understanding of the disease and ultimately helps to guide Intensive Care resources and patient care. We have described the design and statistical analyses plan of the MaastrICCht cohort and plan to present its first results soon. 
medRxiv preprint doi: https://doi.org/10.1101/2020.04.27.20080309; this version posted May 1, 2020. The copyright holder for this preprint (which was not certified by peer review) is the author/funder, who has granted medRxiv a license to display the preprint in perpetuity.

All rights reserved. No reuse allowed without permission.

Conflicts of interest: none declared

Sources of funding: This research received no specific grant from any funding agency in the public, commercial or not-for-profit sectors.

Authors' contributions: Tas, vGassel, vdHorst, vKuijk, vBussel conceived and designed the study, and drafted the manuscript

Heines, Mulder, Acampo-de Jong, Bels, Bennis, Koelmann, Groven, Donkers, vRosmalen, Hermans, Meex, Mingels, Driessen, Kubben, Janssen, Delnoy, Schnabel were involved in the data collection process.

Heijnen, Bekers, Savelkoul, Oude Lashof, Wildberger, Tijssen, Buhre, Sels, Ghossein Doha, Nicolaes, Strauch, Geyik, Walraven, Stehouwer, Verbunt, vMook, vSanten, Aries, vdPoll, Bergmans, critically reviewed the manuscript.

All authors read and approved the final manuscript. 
medRxiv preprint doi: https://doi.org/10.1101/2020.04.27.20080309; this version posted May 1, 2020. The copyright holder for this preprint (which was not certified by peer review) is the author/funder, who has granted medRxiv a license to display the preprint in perpetuity.

All rights reserved. No reuse allowed without permission.

\section{REFERENCES}

1. Gattinoni L, Coppola S, Cressoni M, et al. Covid-19 Does Not Lead to a "Typical" Acute Respiratory Distress Syndrome. Am J Respir Crit Care Med. 2020.

2. Arabi YM, Murthy S, Webb S. COVID-19: a novel coronavirus and a novel challenge for critical care. Intensive Care Med. 2020.

3. Zhang J, Wang X, Jia X, et al. Risk factors for disease severity, unimprovement, and mortality of COVID-19 patients in Wuhan, China. Clin Microbiol Infect. 2020.

4. Organisation WH. Epidemiology: Q\&A: similarities and differences - COVID19 and influenza. 2020;viewed 16.04.2020:https://www.who.int/news-room/q-a-detail/q-asimilarities-and-differences-covid-19-and-influenza.

5. $\quad$ Phua J, Weng L, Ling L, et al. Intensive care management of coronavirus disease 2019 (COVID-19): challenges and recommendations. Lancet Respir Med. 2020.

6. loannidis JPA, Axfors C, Contoupoulos-loannidis DG. Population-level COVID-19 mortality risk for non-elderly individuals overall and for non-elderly individuals without underlying diseases in pandemic epicenters. medRxiv. 2020.

7. Klok FA, Kruip M, van der Meer NJM, et al. Incidence of thrombotic complications in critically ill ICU patients with COVID-19. Thromb Res. 2020.

8. Zhou F, Yu T, Du R, et al. Clinical course and risk factors for mortality of adult inpatients with COVID-19 in Wuhan, China: a retrospective cohort study. Lancet. 2020;395(10229):1054-62.

9. Whittle JS, Pavlov I, Sacchetti AD, et al. Respiratory Support for Adult Patients with COVID-19. JECEP. 2020.

10. Madjid M, Safavi-Naeini P, Solomon SD, et al. Potential Effects of Coronaviruses on the Cardiovascular System: A Review. JAMA Cardiol. 2020.

11. Blankman P, Hasan D, Erik G, et al. Detection of 'best' positive end-expiratory pressure derived from electrical impedance tomography parameters during a decremental positive end-expiratory pressure trial. Crit Care. 2014;18(3):R95.

12. Blankman P, Shono A, Hermans BJ, et al. Detection of optimal PEEP for equal distribution of tidal volume by volumetric capnography and electrical impedance tomography during decreasing levels of PEEP in post cardiac-surgery patients. $\mathrm{Br} J$ Anaesth. 2016;116(6):862-9.

13. Frerichs I, Amato $\mathrm{MB}$, van $\mathrm{Kaam} \mathrm{AH}$, et al. Chest electrical impedance tomography examination, data analysis, terminology, clinical use and recommendations: consensus statement of the TRanslational EIT developmeNt stuDy group. Thorax. 2017;72(1):8393.

14. Heines SJH, Strauch U, van de Poll MCG, et al. Clinical implementation of electric impedance tomography in the treatment of ARDS: a single centre experience. $J$ Clin Monit Comput. 2019;33(2):291-300.

15. Wang $\mathrm{Y}$, Kang $\mathrm{H}$, Liu X, et al. Combination of RT-qPCR testing and clinical features for diagnosis of COVID-19 facilitates management of SARS-CoV-2 outbreak. J Med Virol. 2020.

16. Liu Y, Sun W, Guo Y, et al. Association between platelet parameters and mortality in coronavirus disease 2019: Retrospective cohort study. Platelets. 2020:1-7.

17. Henry BM, de Oliveira MHS, Benoit S, et al. Hematologic, biochemical and immune biomarker abnormalities associated with severe illness and mortality in coronavirus disease 2019 (COVID-19): a meta-analysis. Clin Chem Lab Med. 2020.

18. Wilkinson MD, Dumontier M, Aalbersberg IJ, et al. The FAIR Guiding Principles for scientific data management and stewardship. Sci Data. 2016;3:160018.

19. Du RH, Liang LR, Yang CQ, et al. Predictors of Mortality for Patients with COVID-19 Pneumonia Caused by SARS-CoV-2: A Prospective Cohort Study. Eur Respir J. 2020.

20. Duca A, Piva S, Foca E, et al. Calculated Decisions: Brescia-COVID Respiratory Severity Scale (BCRSS)/Algorithm. Emerg Med Pract. 2020;22(5 Suppl):CD1-CD2. 
medRxiv preprint doi: https://doi.org/10.1101/2020.04.27.20080309; this version posted May 1, 2020. The copyright holder for this preprint (which was not certified by peer review) is the author/funder, who has granted medRxiv a license to display the preprint in perpetuity.

All rights reserved. No reuse allowed without permission.

21. Ruan Q, Yang K, Wang W, et al. Correction to: Clinical predictors of mortality due to COVID-19 based on an analysis of data of 150 patients from Wuhan, China. Intensive Care Med. 2020.

22. Ruan Q, Yang K, Wang W, et al. Clinical predictors of mortality due to COVID-19 based on an analysis of data of 150 patients from Wuhan, China. Intensive Care Med. 2020.

23. Wynants L, Van Calster B, Bonten MMJ, et al. Prediction models for diagnosis and prognosis of covid-19 infection: systematic review and critical appraisal. BMJ. 2020;369:m1328.

24. Wiersema R, Eck RJ, Haapio $M$, et al. Burden of acute kidney injury and 90-day mortality in critically ill patients. BMC nephrology. 2019;21(1):1.

25. Guan WJ, Liang WH, Zhao Y, et al. Comorbidity and its impact on 1590 patients with Covid-19 in China: A Nationwide Analysis. Eur Respir J. 2020.

26. WHO. International severe acute respiratory and emerging infection consortium, SPRINT-SARI. 2020(viewed 16.04.2020):https://isaric.tghn.org/sprint-sari.

27. Linschoten, Asselbergs FW. CAPACITY-COVID: a European registry to determine the role of cardiovascular disease in the COVID-19 pandemic. Eur Heart J. 2020.

28. Pan C, Chen L, Lu C, et al. Lung Recruitability in SARS-CoV-2 Associated Acute Respiratory Distress Syndrome: A Single-center, Observational Study. Am J Respir Crit Care Med. 2020.

29. Suarez-Sipmann F, Bohm SH, Tusman G, et al. Use of dynamic compliance for open lung positive end-expiratory pressure titration in an experimental study. Crit Care Med. 2007;35(1):214-21.

30. Rodriguez-Morales AJ, Cardona-Ospina JA, Gutierrez-Ocampo E, et al. Clinical, laboratory and imaging features of COVID-19: A systematic review and meta-analysis. Travel Med Infect Dis. 2020:101623.

31. He J, Wu B, Chen Y, et al. Characteristic ECG Manifestations in Patients with COVID19. Can J Cardiol. 2020.

32. Rubin GD, Ryerson CJ, Haramati LB, et al. The Role of Chest Imaging in Patient Management during the COVID-19 Pandemic: A Multinational Consensus Statement from the Fleischner Society. Chest. 2020.

33. Colombi D, Bodini FC, Petrini M, et al. Well-aerated Lung on Admitting Chest CT to Predict Adverse Outcome in COVID-19 Pneumonia. Radiology. 2020:201433.

34. Zeng Y, Cai Z, Xianyu Y, et al. Prognosis when using extracorporeal membrane oxygenation (ECMO) for critically ill COVID-19 patients in China: a retrospective case series. Crit Care. 2020;24(1):148.

35. Edelson DP, Sasson C, Chan PS, et al. Interim Guidance for Basic and Advanced Life Support in Adults, Children, and Neonates With Suspected or Confirmed COVID-19: From the Emergency Cardiovascular Care Committee and Get With the Guidelines $((\mathrm{R}))$-Resuscitation Adult and Pediatric Task Forces of the American Heart Association in Collaboration with the American Academy of Pediatrics, American Association for Respiratory Care, American College of Emergency Physicians, The Society of Critical Care Anesthesiologists, and American Society of Anesthesiologists: Supporting Organizations: American Association of Critical Care Nurses and National EMS Physicians. Circulation. 2020.

36. Li X, Xu S, Yu M, et al. Risk factors for severity and mortality in adult COVID-19 inpatients in Wuhan. J Allergy Clin Immunol. 2020.

37. Curtis JR, Kross EK, Stapleton RD. The Importance of Addressing Advance Care Planning and Decisions About Do-Not-Resuscitate Orders During Novel Coronavirus 2019 (COVID-19). JAMA. 2020.

38. Wasserstein RL. ASA Statement on Statistical Significance and P-Values. . The American Statistician. 2016;70:129-33.

39. Rothman KJ, Greenland S, Lash TL. Modern Epidemiology. 3th ed: Lippincott Williams \& Wilkins; 2008.

40. Hiemstra B, Keus F, Wetterslev J, et al. DEBATE-statistical analysis plans for observational studies. BMC Med Res Methodol. 2019;19(1):233. 
medRxiv preprint doi: https://doi.org/10.1101/2020.04.27.20080309; this version posted May 1, 2020. The copyright holder for this preprint (which was not certified by peer review) is the author/funder, who has granted medRxiv a license to display the preprint in perpetuity. All rights reserved. No reuse allowed without permission.

41. Lorusso R, Alexander $\mathrm{P}, \mathrm{Rycus} \mathrm{P}$, et al. The Extracorporeal Life Support Organization Registry: update and perspectives. Ann Cardiothorac Surg. 2019;8(1):93-8.

42. Maves RC, Downar J, Dichter JR, et al. Triage of scarce critical care resources in COVID-19: an implementation guide for regional allocation An expert panel report of the Task Force for Mass Critical Care and the American College of Chest Physicians. Chest. 2020.

43. CDC Covid Response Team. Geographic Differences in COVID-19 Cases, Deaths, and Incidence - United States, February 12-April 7, 2020. MMWR Morb Mortal Wkly Rep. 2020;69(15):465-71.

44. Kiekens $C$, Boldrini $P$, Andreoli $A$, et al. Rehabilitation and respiratory management in the acute and early post-acute phase. "Instant paper from the field" on rehabilitation answers to the Covid-19 emergency. Eur J Phys Rehabil Med. 2020.

45. Swiss Society Of Intensive Care Medicine. Recommendations for the admission of patients with COVID-19 to intensive care and intermediate care units (ICUs and IMCUs). Swiss Med Wkly. 2020;150:w20227. 